\title{
Production of Extracellular Xylanase from Intestinal Bacteria in Termite
}

\author{
Muhammad Maqsud Hossain ${ }^{1 *}$, M Aftab Uddin², M Abdul Malek³, SAM Khairul Basharr ${ }^{1}$ Parvin Noor ${ }^{4}$ and \\ M Majibur Rahman ${ }^{3}$ \\ ${ }^{1}$ Department of Life Sciences, North South University, Plot \# 15, Block B, Bashundhara Residential Area, Dhaka 1213, Bangladesh, ${ }^{2}$ Department of \\ Biochemistry \& Molecular Biology, University of Dhaka, Dhaka 1000, Bangladesh, ${ }^{3}$ Department of Microbiology, University of Dhaka, Dhaka 1000, \\ Bangladesh, ${ }^{4}$ Food Microbiology Section, Institute of Food Science \& Technology (IFST), Bangladesh Council of Scientific \& Industrial Research \\ (BCSIR), Dr Qudrat-e-Khuda Road, Dhaka 1205, Bangladesh
}

[Received 12 December 2008; Accepted 07 November 2009]

\begin{abstract}
Although the involvement of intestinal bacteria in the degradation of lignocellulosic materials is poorly understood xylanolytic activity of termite has been studied extensively. The present study was designed to identify potential xylanolytic bacteria from termite intestine and the isolated bacterium was studied with a view to preparing low cost medium and optimizing the cultural conditions in Dubos liquid medium. The bacterium produced highest activity of the enzyme $(0.86 \mathrm{U} / \mathrm{ml})$ on birchwood xylan as carbon substrate. Wheat bran a relatively cheap lignocellulosic material was found as good inducer of the enzyme. When grown on 4\% wheat bran in Dubos liquid medium with an initial pH 6.0 under shaking incubation at $200 \mathrm{rpm}$ at $40^{\circ} \mathrm{C}$ for $24 \mathrm{~h}$, the bacterium produced the maximum activity of the extracellular xylanase $(1.5 \mathrm{U} / \mathrm{ml})$. These results strongly indicated that the bacterium from the intestine in termite is able synthesize xylanase activity on various substrate and the enzyme production can be increased by optimizing the overall cultivation parameters.
\end{abstract}

Keywords: Xylanase, Termite intestinal bacteria

\section{Introduction}

Xylans are hemicellulosic compounds and are the second most abundant natural polysaccharide behind cellulose ${ }^{1}$. These compounds are present in the cell wall and in the middle lamella of plant cells. Xylanolytic enzymes are a group of enzymes that are involved in the hydrolysis of xylans and arabinoxylan polymers. These enzymes include endo-1,4- $\beta$-xylanase, $\beta$-xylosidase, $\alpha$-arabinofuranosidase and acetylxylan esterase ${ }^{2}$. Xylanases hydrolyze $1,4-\beta$-D-xylosidic linkages in xylan to produce xylooligosaccharide.

The enzyme system employed for the breakdown of xylan may become important tools in establishing economically and ecologically beneficial processes for using the second most abundant renewable polysaccharide in nature and their biological potential is unlimited at present time. The potential applications of xylanases include the bioconversion of lignocelluloses into sugars, ethanol and other useful substances, clarifying juices and wines, extracting plant oils, coffee and starch and improving the nutritional value of silage and green feed ${ }^{3}$. In recent years, interests have been growing in the application of xylanase in the pulp and paper industr ${ }^{4}$. These xylanase-based processes reduce or replace the ecologically harmful alkaline extraction of hemicelluloses and the need for chlorine in bleaching, leading to a mixture of fermentable sugars instead of polluting waste liquors ${ }^{5}$. In addition xylanases may be applied to upgrade (or softening) jute fibre of low quality, which comprises about the one-third of the total world jute production ${ }^{6}$.

The bioconversion of xylan into simple sugars is brought about by xylanolytic enzymes of several fungi, bacteria, actinomycetes etc. Several species of organisms are known to produce xylanase and $\beta$-xylosidase, which enables xylan to hydrolyze. Genomic libraries were constructed from microbial DNA isolated from insect intestinal tracts from the orders Isoptera (termites) and Lepidoptera (moths). Using a targeted functional assay, these environmental DNA libraries were screened for genes that encode proteins with xylanase activity ${ }^{7}$. Unusual bacterial xylanases were obtained from termite gut, which indicates the involvement of bacterial species in the degradation of hemicellulosic materials in conjunction with symbiotic fungus and protozoa, which have already been reported. Nevertheless, microbial species of termite origin are involved in the degradation of hemicelluloses are poorly defined. Further investigation required identifying microorganisms that produce xylanase.

The present study aims the isolation of potential xylanolytic bacteria from termite gut towards obtaining substantial enzyme preparation for its technical application. Furthermore, the

*Corresponding author:

Muhammad Maqsud Hossain, Senior Lecturer, Department of Life Sciences, North South University, Plot \# 15, Block B, Bashundhara Residential Area, Dhaka 1213, Bangladesh

Tel (Office): (02) 9885611-20, Ext. 394; Cell: 01823 158773; Fax: +880(02) 8823030; E-mail: hossainm@northsouth.edu 
clarification of the xylanolytic system in termite is of importance in understanding not only the xylanolytic system of termites but also the evolution of the interaction between termites and their intestinal symbionts.

\section{Materials and Methods}

\section{Microorganism}

A single worker termite was washed several times with sterile saline water. Under the low power magnification (x20) the termite placed on the nutrient agar medium was operated by using sterile sharp needle. To get isolated colonies the gut contents were streaked onto the medium by sterile loop $^{8}$. The potential xylanolytic isolate was identified from the termite gut following the modified procedure of Choi et al. ${ }^{9}$, was selected for further investigation and the strain was maintained in nutrient agar slant.

\section{Substrate preparation}

Air-dried cellulosic substrates such as rice straw, jute cuttings, saw dust and corn cobs were separately sieved in bulk through a large 1 -mm screen, and particle sizes less than $1 \mathrm{~mm}$ were used in this study. These substrates were pretreated by boiling in $0.5 \%$ $\mathrm{NaOH}(0.1 \mathrm{~g} \mathrm{NaOH} / \mathrm{g}$ substrate) for $1 \mathrm{~h}$ following the method of Gray et al. ${ }^{10}$. The commercial substrates such as xylan, xylose, glycerol, glycerol etc. were used without pretreatment.

\section{Growth measurement}

The total viable bacterial cells in a liquid culture were determined by the serial dilution technique. One-tenth $\mathrm{ml}$ of an appropriated dilution was aseptically spread onto nutrient agar plates and incubated at $37^{\circ} \mathrm{C}$ for $24 \mathrm{~h}$ and the number of colonies was counted with a colony counter.

\section{Production of xylanase by intestinal bacterium in termite}

The potential xylanolytic bacteria isolated from termite gut was investigated to determine the growth for the maximum production of the extracellular xylanase during growth on xylan substrate. The bacterial isolate was grown in $50 \mathrm{ml}$ Dubos liquid medium containing $1 \%$ of the substrate in a $250-\mathrm{ml}$ conical flask at $40^{\circ} \mathrm{C}$ in the orbital shaker for different growth periods $(12,18,24,30,26$ and $42 \mathrm{~h}$ ). Duplicate samples were collected for determination of growth and the enzyme activity.

\section{Enzyme assays}

Xylanase, $\alpha$-mannanase, carboxymethyl cellulase (CMcase), cellulase and $\alpha$-amylase activities were determined using $1 \%$ birchwood xylan, $0.1 \%$ guar gum, $1 \%$ carboxymethyl cellulose (CMC), 1\% cellulose and 1\% soluble starch solutions, respectively. All the substrates were available from Sigma (USA). The reaction mixture containing $0.1 \mathrm{ml}$ substrate and $0.1 \mathrm{ml}$ suitable diluted enzyme solution was incubated at $55^{\circ} \mathrm{C}$ for $30 \mathrm{~min}$. The amount of reducing sugar produced was subsequently determined by the method of Nelson ${ }^{11}$. One unit (U) of enzyme activity was defined as the amount of enzyme that liberates reducing sugars equivalent to one $\mu \mathrm{mol}$ of respective monosaccharide (xylose or glucose) per min under assay conditions. Specific activity of the enzyme was obtained by dividing enzyme activity in unit by total protein in micro-Lowry method ${ }^{12}$. It was expressed as U/mg under standard condition.

\section{Estimation of protein}

The protein content of the samples was determined according to the method described by Lowry et al. ${ }^{12}$.

\section{Chemical assay}

The total reducing sugars present in the culture supernatant were estimated using the method of Nelson-Somongyi ${ }^{13}$.

\section{Results and Discussion}

Termite microbial species involved in the degradation of hemicelluloses are poorly defined ${ }^{14}$. Four xylanases have been purified and characterized from termite and its symbiotic fungus ${ }^{15}$, but there is paucity of information on the involvement of bacterial species of termite origin in the degradation of hemicellulosic materials. One of the objectives was the screening out the most potential xylanolytic isolate from termite intestine as there is a report ${ }^{7}$ on the possible role of termite intestinal bacteria in the degradation of lignocellulosic materials.

Effort was taken to find out the optimum conditions for the maximum production of xylanase from the most potential isolate. The bacterium was grown on various substrates and environmental conditions in shake-flask cultivations. The viable cell count and xylanase activity varied with incubation time for the bacteria. Production of xylanase was found to be growth related as increasing enzyme activity $(0.72 \mathrm{U} / \mathrm{ml})$ was found after $24 \mathrm{~h}$ with the highest number of viable cells $\left(8.5 \times 10^{8}\right.$ cells $\left./ \mathrm{ml}\right)$ (Figure 1$)$. In addition to xylanase activity, the bacterial isolate showed the ability to produce other hydrolytic enzymes such as cellulase, carboxymethylcellulase (CMCase), á-mannanase, á-amylase and protease. Based on the results of this study, it can be concluded that the formation of xylanase, cellulose, mannanase and amylase is inducible in the bacterium from termite gut. This is in agreement with several fungi that have been closely investigated with respect to the regulation of xylanase or cellulase biosynthesis ${ }^{16-18}$.

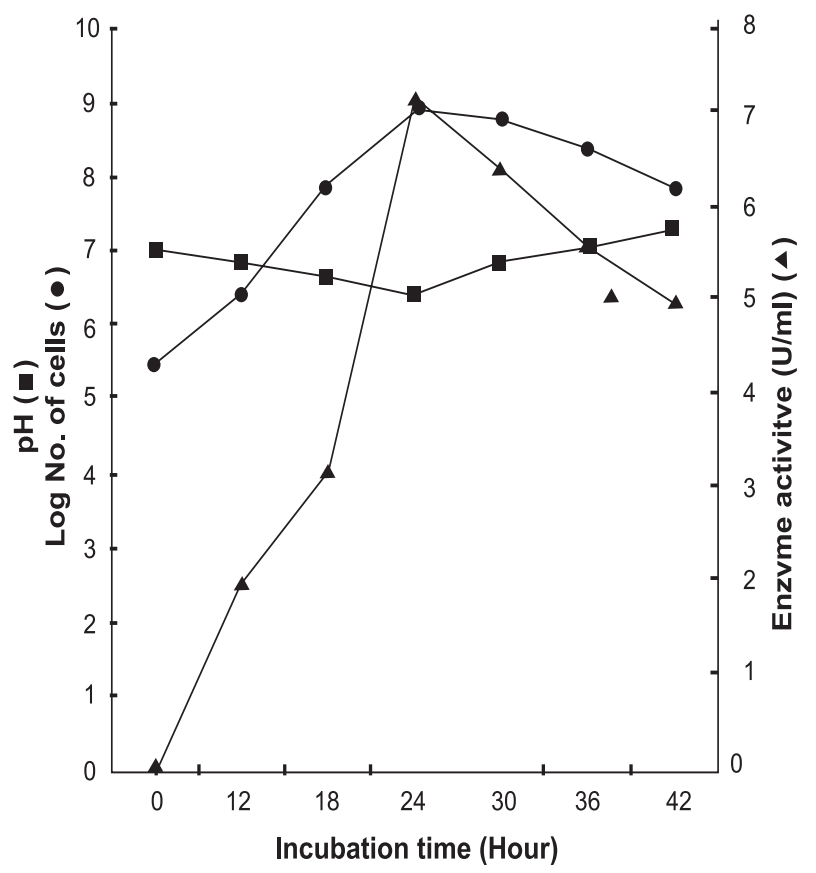

Figure 1. Production of xylanase by termite intestinal xylanolytic bacterium in Dubos liquid medium supplemented with $1 \%$ xylan as substrate. 
Effect of initial culture $\mathrm{pH}$ and temperature on the enzyme production was studied. The bacterial isolate was grown in Dubos liquid medium of different culture $\mathrm{pH}$ values ( $\mathrm{pH}$ 4.0-8.0) containing $1 \%(\mathrm{w} / \mathrm{v})$ xylan as substrate at $40^{\circ} \mathrm{C}$ in a shaker for $24 \mathrm{~h}$. The maximum activity was found with the initial culture $\mathrm{pH}$ of 7.0 (Figure 2). To find the temperature optima for the production of enzyme the isolate was grown in Dubos liquid medium under shaking incubation at different temperature $\left(30-60^{\circ} \mathrm{C}\right.$ for $24 \mathrm{~h}$ at $\mathrm{pH}$ 7.0. The maximum activity was found at $40^{\circ} \mathrm{C}$ (Figure 3 ).

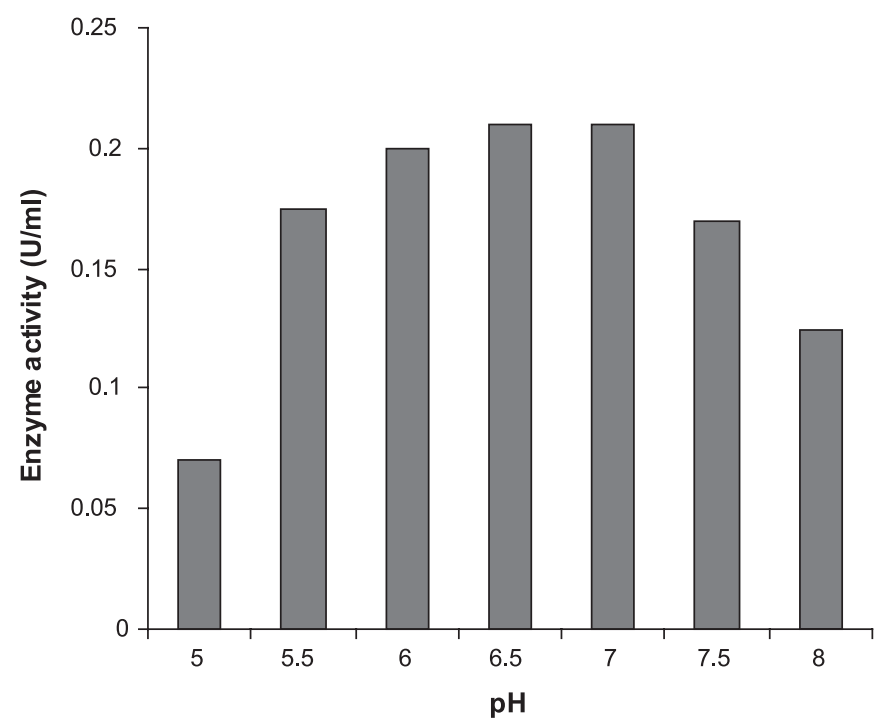

Figure 2. Effect of initial culture $p H$ on production of extracellular xylanase by termite intestinal bacterium.

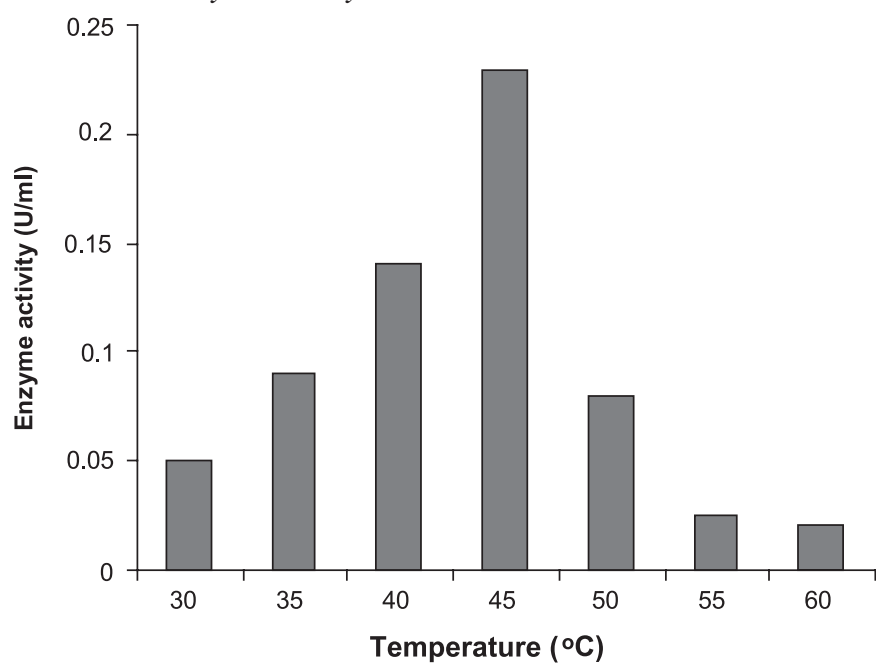

Figure 3. Effect of cultivation temperature on production of extracellular xylanase by termite intestinal bacterium.

Various xylan rich substrates, mainly agricultural residues were evaluated for xylanase production. $\mathrm{NaNO}_{3}$ was supplemented as an inorganic nitrogen source. Comparison of results showed that birchwood xylan induced maximum activity of xylanase $(0.86 \mathrm{U} /$ $\mathrm{ml})$. Among the natural lignocellulosic materials wheat bran induced considerable amount of the enzyme $(0.56 \mathrm{U} / \mathrm{ml})$, whereas other steam-treated substrates gave relatively low amount of the enzyme activity (Figure 4). Kosugi et al. ${ }^{19}$ also reported that xylanase induction by Clostridium cellulovorans, an anaerobic, mesophilic, cellulolytic bacterium, was highest when birchwood xylan was used as the sole source of carbon in the medium.

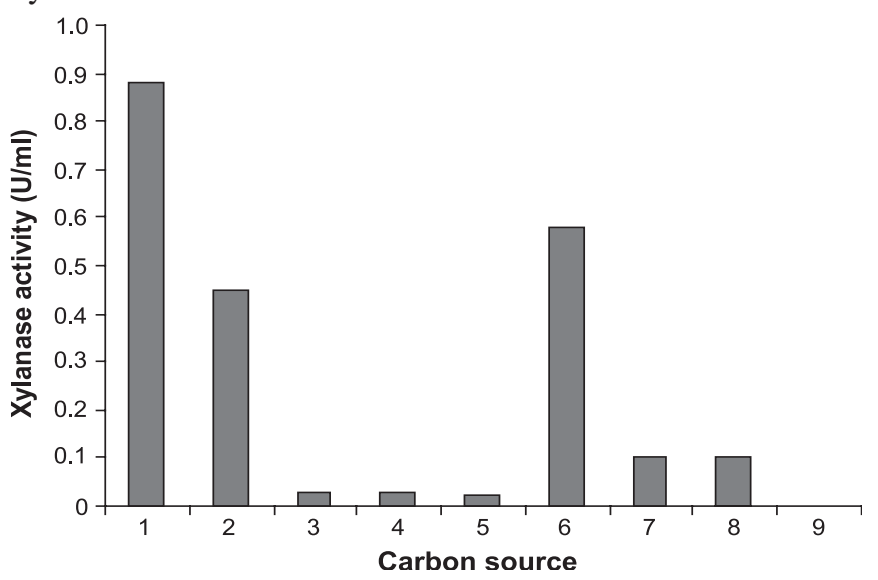

Figure 4. Effect of different carbon sources on the production of extracellular xylanase by termite intestinal bacterium. $1=$ Xylan 2 = Xylose; 3 = Glycerol; 4 = Glucose; 5 = Corncobs; $6=$ Wheat bran; 7 = Jute powder; 8 = Rice straw; 9 = Saw dust.

Though xylan was found to be the best inducer of the xylanase enzyme, it is very expensive to be used as substrate for commercial production of the enzyme. Since wheat bran was found to be the most potent carbon source among the lignocellulosic substrates, different concentration of the substrate (0.5-7.0\% w/v), in Dubos liquid medium at $40^{\circ} \mathrm{C}$ for $24 \mathrm{~h}$ under shaking incubation, was used to find out the optimum concentrations of wheat bran for the maximum production of xylanase. The highest production (0.91$0.96 \mathrm{U} / \mathrm{ml}$ ) was observed when the substrate concentrations were between 3.0 and $5.0 \%$ (Figure 5). From a commercial viewpoint, the use of wheat bran is very advantageous because, it is very cheap and readily available in all seasons everywhere in the world. Unlike pure xylan, different biopolymer residues of this substrate may cause contamination with the extracellular enzyme products rendering the problems in enzyme recovery and purification.

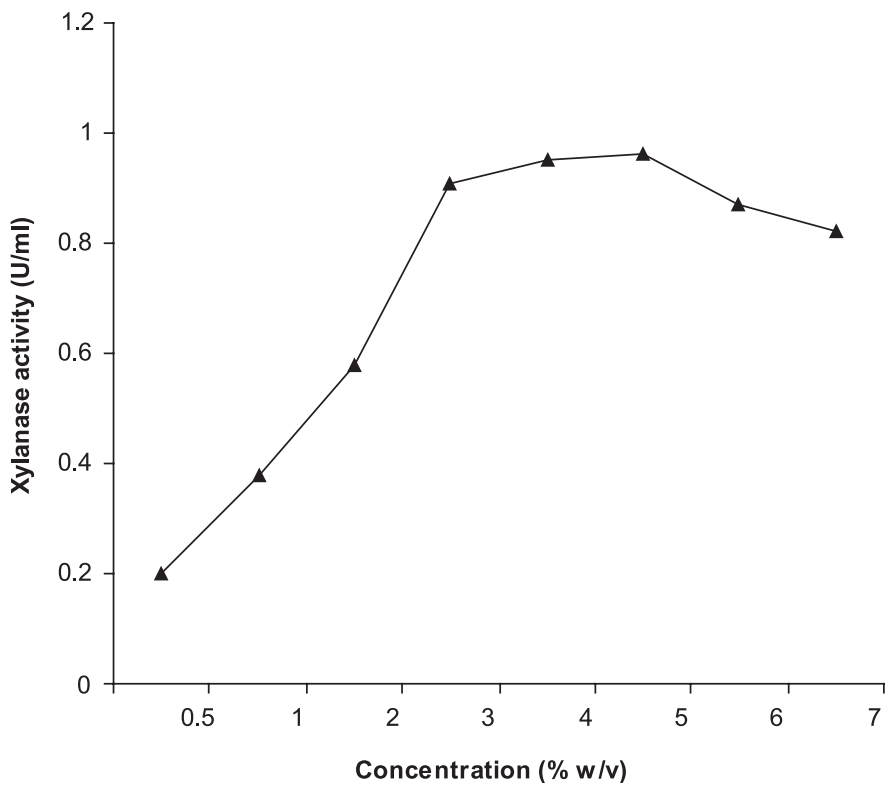

Figure 5. Effect of different concentrations of wheat bran on the production of extracellular xylanase by termite intestinal bacterium. 
Using 3\% (w/v) wheat bran as carbon source various inorganic and organic nitrogen substrates were supplemented in medium for the enzyme production by the bacterium. Inorganic nitrogen sources at a level equivalent to $0.5 \mathrm{~g} / \mathrm{l}$ of culture medium were tested for a preliminary investigation. Inorganic nitrogen sources in combination with yeast extract $(0.25 \mathrm{~g} / \mathrm{l})$ were used for comparative studies. Among the inorganic and organic nitrogen sources yeast extract and $\mathrm{NH}_{4} \mathrm{NO}_{3}$ encouraged the highest amount of enzyme biosynthesis (1.4 U/ml) (Figure 6).

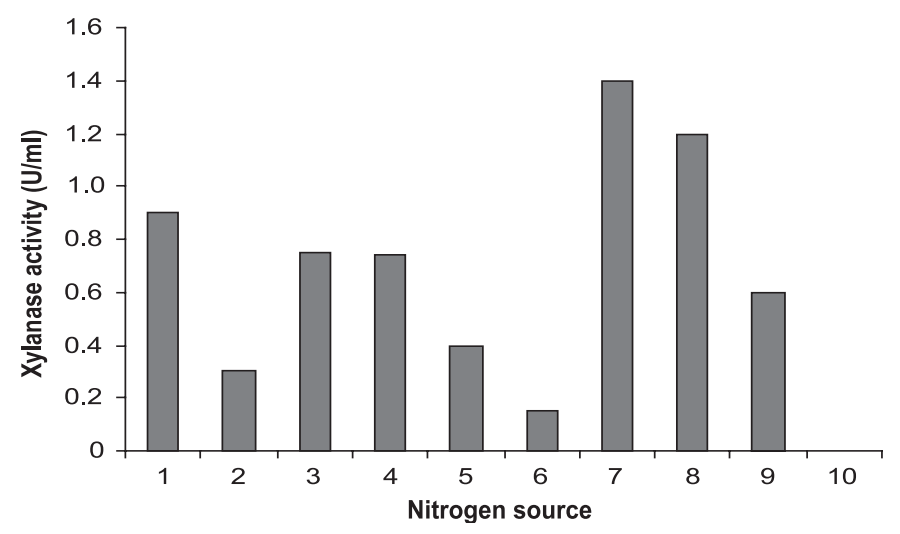

Figure 6. Effect of different nitrogen sources on production of xylanase by termite intestinal bacterium. $1=$ Yeast extract; $2=$ $\mathrm{NH}_{4} \mathrm{NO}_{3} ; 3=\left(\mathrm{NH}_{4}\right)_{2} \mathrm{SO}_{4} ; 4=\mathrm{KNO}_{3} ; 5=\mathrm{NaNO}_{3} ; 6=$ Yeast extract $+\mathrm{NH}_{4} \mathrm{NO}_{3} ; 7=$ Yeast extract $+\left(\mathrm{NH}_{4}\right)_{2} \mathrm{SO}_{4} ; 8=$ Yeast extract $+\mathrm{KNO}_{3} ; 9=$ Yeast extract $+\mathrm{NaNO}_{3}$.

To find the appropriate concentration of yeast extract in the enzyme production medium, the bacterium was grown in Dubos liquid medium with different concentrations of yeast extract (0.01-1.0\% $\mathrm{w} / \mathrm{v})$ at $40^{\circ} \mathrm{C}$ for $24 \mathrm{~h}$ under shaking incubation. A concentration of $0.025 \%(\mathrm{w} / \mathrm{v}) \mathrm{NH}_{4} \mathrm{NO}_{3}$ was incorporated into each of the medium. Increased induction of the enzyme was found with the increased amount of yeast extract (Figure 7). The highest enzyme activity $(1.65 \mathrm{U} / \mathrm{ml})$ was found at concentration range of 0.05 $0.06 \%(\mathrm{w} / \mathrm{v})$ yeast extract. Beyond this concentration no remarkable change in the enzyme activity was found.

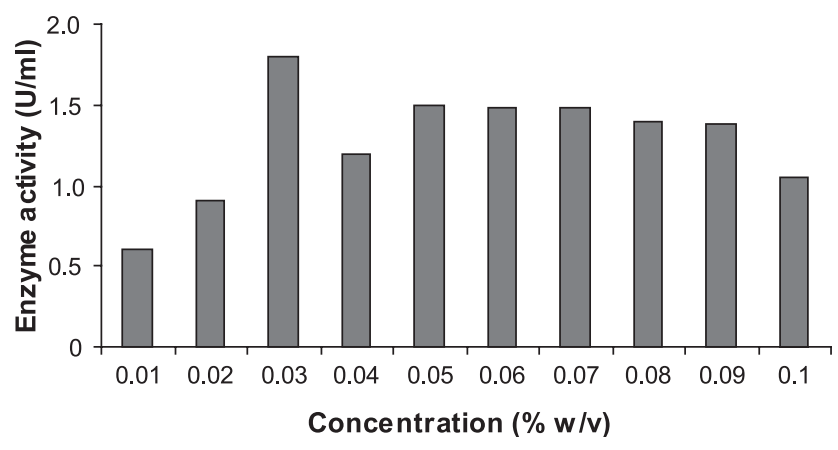

Figure 7. Effect of different concentrations of yeast extract on production of crude xylanase by termite intestinal bacterium.

The effect of agitation rate on the production of xylanase was investigated (Table 1). The bacterium was grown in Dubos liquid medium with $1 \%$ (w/v) xylan at an initial culture $\mathrm{pH}$ of 7.0 for $24 \mathrm{~h}$ under shaking and static conditions. The amount of enzyme produced under shaking condition was considerably higher (1.4 $\mathrm{U} / \mathrm{ml})$ than that produced under static condition $(0.3 \mathrm{U} / \mathrm{ml})$. Further investigation was carried out to find out the optimum-shaking rate. The bacterium was cultivated in the same medium with optimum cultural and environmental conditions under various shaking rate (15, 175, 200 and 225 rpm.). Maximum amount of xylanase was produced at shaking rate of $200 \mathrm{rpm}$. Further increase of agitation rate resulted excessive foaming and reduced enzyme activity. Experiment was also carried out using $200 \mathrm{ml}$ of culture medium in a 1,000-ml flask and $125 \mathrm{ml}$ of medium in a 250-ml flask. The bacterium grew well in both flasks under shaking conditions (200 rpm). Higher amount of enzyme was produced in 1,000-ml flask than 250-ml flask. It was apparent from the study that the bacterium produced maximum level of enzyme under shaking incubation $(200 \mathrm{rpm})$ with the flask volume to medium volume ratio of 5:1.

Table 1. Effect of shaking and flask volume/medium volume ratio on the production of xylanase by the bacterium isolated from intestine of termite

\begin{tabular}{lc}
\hline Growth condition & Xylanase activity $(\mathrm{U} / \mathrm{ml})$ \\
\hline Shaking (rpm) & 1.03 \\
150 & 1.30 \\
175 & 1.40 \\
200 & 1.10 \\
225 & 0.30 \\
Static & \\
Flask volume to medium volume ratio & \\
$5: 1$ & 1.50 \\
$2: 1$ & 1.30 \\
\hline
\end{tabular}

It can be inferred that high amount of the enzyme could be produced by the intestinal bacteria in termite after optimization of cultural medium and culture conditions in shake-flask system where oxygen and culture $\mathrm{pH}$ are not properly controlled. Therefore, production efficiency of the bacterium can be improved either by controlled fermentation system and more production of the enzyme can be expected when the bacterium can be cultivated in a semi-continuous or batch fermentation system under controlled conditions of $\mathrm{pH}$ and oxygen supply. The potential xylanolytic bacterium isolated from termite gut requires further investigation with regard to its identification, comparison of its ability to produce extracellular xylanase with other potential xylanolytic organisms and expression of this enzyme in a suitable organism for its industrial application.

\section{References}

1. Collins T, Gerday C \& Feller G. 2005. Xylanases, xylanase families and extremophilic xylanases. FEMS Microbiol Rev. 29: 3-23. 
2. Biely P, Kluepfel D, Morosoli R \& Shareck F. 1993. Mode of action of three endo-beta-1,4-xylanases of Streptomyces lividans. Biochim Biophys Acta. 1162: 246-54.

3. Gilbert M, Yaguchi M, Watson DC, Wong KK, Breuil C \& Saddler JN. 1993. A comparison of two xylanases from the thermophilic fungi Thielavia terrestris and Thermoascus crustaceus. Appl Microbiol Biotechnol. 40: 508-514.

4. Paice JA. 1988. The phenomenon of analgesic tolerance in cancer pain management. Oncol Nurs Forum. 15: 455-460.

5. Linko M, Viikari L \& Suihko ML. 1984. Hydrolysis of xylan and fermentation of xylose to ethanol. Biotechnol Adv. 2: 233-252.

6. Ghose BL \& Dutta AK. 1980. Enzymatic softening and upgrading of lignocellulosic fibres. I. The softening and cleaning of low grade mesta and jute. J Textile Inst. 71: 108-116.

7. Brennan Y, Callen WN, Christoffersen L, Dupree P, Goubet F, Healey S, Hernandez M, Keller M, Li K, Palackal N, Sittenfeld A, Tamayo G, Wells S, Hazlewood GP, Mathur EJ, Short JM, Robertson DE \& Steer BA. 2004. Unusual microbial xylanases from insect guts. Appl Environ Microbiol. 70:3609-3617.

8. Chan ECS, Pelczar MJ Jr \& Krieg NR. 1993, Laboratory Exercises in Microbiology, $6^{\text {th }}$ edn. McGraw-Hill, London.

9. Choi ID, Kim HY \& Choi YJ. 2000. Gene cloning and characterization of alpha-glucuronidase of Bacillus stearothermophilus no. 236. Biosci Biotechnol Biochem. 64: 2530-2537.

10. Gray PP, Hendy NA \& Dunn NW. 1978. Digestion by cellulolytic enzymes of alkali pretreated baggage. J Aust Inst Agric Sci. 44: 210212.
11. Nelson N. 1944. A photometric adaptation of the somogyi method for the determination of glucose. J Biol Chem. 153: 375-380.

12. Lowry OH, Rosebrough NJ, Far AL \& Randal RJ. 1951. Protein measurement with the Folin-phenol reagent. J Biol Chem. 193: 265275.

13. Somogyi. 1940. A new reagent for the determination of sugar. 160: 61-68.

14. Schafer A, Konrad R, Kuhnigk T, Kampfer P, Hertel H \& Konig H. 1996. Hemicellulose-degrading bacteria and yeasts from the termite gut. J Appl Bacteriol. 80: 471-478.

15. Matoub M \& Rouland C. 1995. Purification and properties of the xylanases from the termite Macrotermes bellicosus and its symbiotic fungus Termitomyces sp. Comp Biochem Physiol B Biochem Mol Biol. 112: 629-635.

16. Coughlan MP \& Hazelwood GP. 1993. $\beta$-1,4-D-Xylan-degrading enzyme systems: Biochemistry, molecular biology and applications. Biotechnol Appl Biochem. 17: 259-289.

17. Haltrich D, Nidetzky B, Kulbe KD, Steiner W \& Zupancic S. 1996. Production of fungal xylanases. Bioresource Technol. 58: 137-161.

18. Kubicek CP, Messner R, Gruber F, Mach RL \& Kubicek-Pranz EM. 1993. The Trichoderma cellulase regulatory puzzle: From the interior life of a secretory fungus. Enzyme Microb Technol. 15: 90-99.

19. Kosugi A, Murashima K \& Doi RH. 2001. Characterization of xylanolytic enzymes in Clostridium cellulovorans: Expression of xylanase activity dependent on growth substrates. J Bacteriol. 183(24): 7037-7043. 